\title{
Transgenic mice provide new insights into the role of TGF- $\alpha$ during epidermal development and differentiation
}

\author{
Robert Vassar and Elaine Fuchs ${ }^{1}$ \\ Howard Hughes Medical Institute, Department of Molecular Genetics and Cell Biology, The University of Chicago, Illinois \\ 60637 USA
}

\begin{abstract}
Transforming growth factor- $\alpha$ (TGF- $\alpha$ ) is thought to be the major autocrine factor controlling growth in epidermal cells. To explore further the role of TGF- $\alpha$ in epidermal growth and differentiation, we used a human keratin K14 promoter to target expression of rat TGF- $\alpha$ cDNA to the stratified squamous epithelia of transgenic mice. Unexpectedly, the only regions of epidermis especially responsive to TGF- $\alpha$ overexpression were those that were normally thick and where hair follicle density was typically low. This included most, if not all, body skin from 2-day- to 2-week-old mice, and ear, footpad, tail, and scrotum skin in adult mice. In these regions, excess TGF-a resulted in thicker epidermis and more stunted hair growth. Epidermal thickening was attributed both to cell hypertrophy and to a proportional increase in the number of basal, spinous, granular, and stratum corneum cells. During both postnatal development and epidermal differentiation, responsiveness to elevated TGF- $\alpha$ seemed to correlate with existing epidermal growth factor (EGF) receptor levels, and we saw no evidence for TGF- $\alpha$-mediated control of EGF receptor (EGFR) expression. In adults, no squamous cell carcinomas were detected, but benign papillomas were common, developing primarily in regions of mechanical irritation or wounding. In addition, adult transgenic skin that was still both sensitive to TGF- $\alpha$ and subject to mild irritation displayed localized regions of leukocytic infiltration and granular layer loss, characteristics frequently seen in psoriasis in humans. These unusual regional and developmental effects of TGF- $\alpha$ suggest a natural role for the growth factor in (1) controlling epidermal thickness during development and differentiation, (2) involvement in papilloma formation, presumably in conjunction with TGF- $\beta$, and (3) involvement in psoriasis, in conjunction with some as yet unidentified secondary stimulus stemming from mild mechanical irritation/bacterial infection.
\end{abstract}

[Key Words: TGF- $\alpha$; epidermis; transgenic mice]

Received February 6, 1991; revised version accepted February 28, 1991.

Transforming growth factor- $\alpha$ (TGF- $\alpha$ ) is a potent mitogen belonging to the epidermal growth factor (EGF) family of proteins (for review, see Derynck 1988). TGF- $\alpha$ shares functional and structural homology with EGF, and it binds to the same cell-surface receptor (Massague $1983 a, b)$. It is made as a transmembrane precursor, which exists at the cell surface until proteolytic cleavages at both termini result in its release as an active growth factor (Bringman et al. 1987). Elevated levels of TGF- $\alpha$ have been associated with neoplastic transformation of many cultured cell types (Derynck et al. 1987); and more recently, overexpression of TGF- $\alpha$ in the pancreas, liver, and mammary epithelia of transgenic mice has been correlated with hyperproliferation and neoplasia (Jhappan et al. 1990; Matsui et al. 1990; Sandgren et al. 1990).

EGF was first identified by its ability to stimulate

${ }^{1}$ Corresponding author. growth in newborn, but not adult, mouse epidermis (Cohen 1962; Cohen and Elliot 1963). Relevant to this observation is the finding that EGF receptors (EGFRs) on the surface of basal epidermal cells diminish markedly with age (Green et al. 1983). Unlike EGF, TGF- $\alpha$ is synthesized by epidermal cells (Coffey et al. 1987), and it is even more potent than EGF in stimulating keratinocyte growth and cell migration (Barrandon and Green 1987). In this context, it has been assumed that TGF- $\alpha$ is the major autocrine growth regulator of the epidermis. TGF- $\alpha$ overexpression has also been implicated in human diseases of epidermal hyperproliferation. In psoriasis, a common hyperproliferative skin disorder of unknown etiology, a sixfold increase in TGF- $\alpha$ has been reported for affected (lesional), but not unaffected (nonlesional), regions of the skin, leading to the postulation that TGF- $\alpha$ overexpression might be responsible for the psoriatic phenotype (Gottlieb et al. 1988; Elder et al. 1989). In addition, cultured keratinocytes transfected 
with a constitutive TGF- $\alpha$ transgene give rise to benign skin papillomas when grafted to nude mice (Finzi et al. 1988).

To explore in greater detail the role of TGF- $\alpha$ in controlling the balance between growth and differentiation in the epidermis, we used a K14 keratin gene enhancer and promoter to drive expression of a rat TGF- $\alpha$ cDNA in transgenic mice. Previously, we showed that $\sim 2500 \mathrm{bp}$ of $5^{\prime}$ upstream sequence of the human K14 gene was sufficient to drive expression of a tagged human K14 keratin in basal cells of most stratified squamous epithelia, including epidermis (Vassar et al. 1989). Because $<30$ $\mathrm{ng} / \mathrm{ml}$ TGF- $\alpha$ does not inhibit K14 gene expression in cultured human keratinocytes (Y.-S. Choi and E. Fuchs, unpubl.), we expected this promoter to be active in TGF- $\alpha$-expressing transgenic mice. Here, we describe the characterization of neonatal and adult transgenic mice that overexpress the rat TGF- $\alpha$ cDNA in their stratified squamous epithelia. Our results reveal some unusual and unanticipated developmental and regional perturbations in the epidermis of these mice, which has provided new insights into the natural and evolutionary roles of TGF- $\alpha$ in mammalian epidermis and its possible relation to various human skin diseases involving epidermal hyperproliferation.
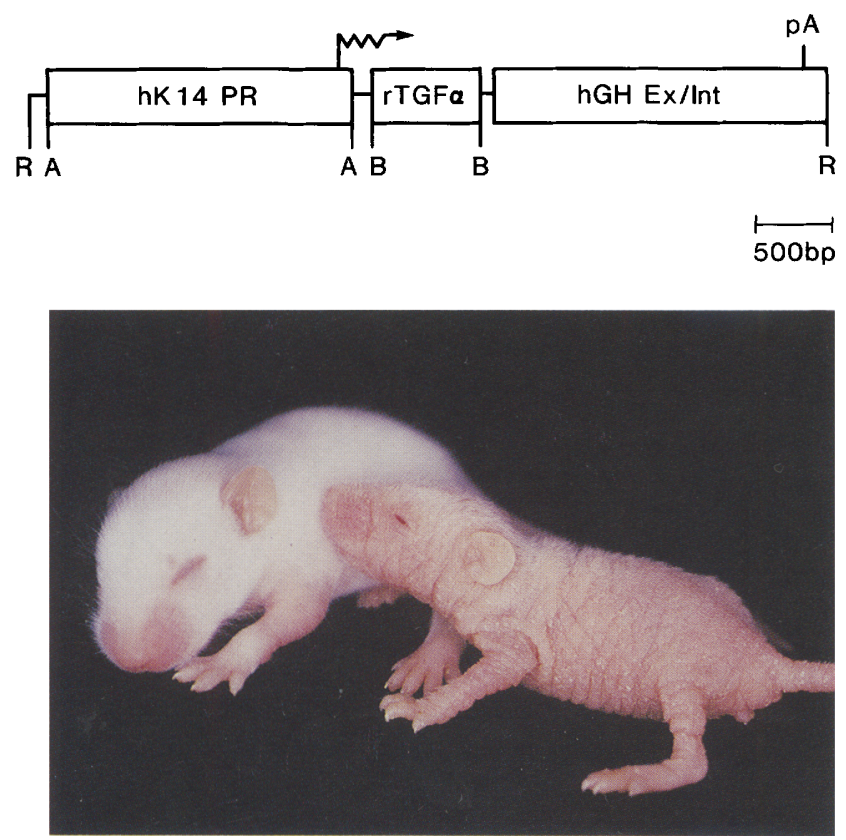

Figure 1. Transgene construct and K14-TGF- $\alpha$ transgenic mouse. (Top) A K14/rat TGF- $\alpha /$ hGH fusion gene was constructed by cloning two fragments into the BamHI and $X b a \mathrm{I}$ sites, respectively, of an expression vector containing the human Kl4 promoter/enhancer (Vassar et al. 1989): (1) the 700-bp $B a m H I$ fragment containing the rat TGF- $\alpha$ cDNA and TGA stop codon, and (2) the BamHI-EcoRI fragment containing most of the hGH gene and polyadenylation signal as $3^{\prime}$ sequence (Sandgren et al. 1990). The control littermate (left) and the transgenic mouse (right) of the $F_{1}$ generation from a K14-TGF- $\alpha$ founder (10A) are shown.

\section{Results \\ Neonatal TGF- $\alpha$ transgenic mice exhibit gross phenotypic abnormalities in their skin}

Figure 1 illustrates the epidermal keratin promoter/ TGF- $\alpha$ cDNA construct used in generation of TGF- $\alpha$ transgenic mice. The strategy of introducing human growth hormone ( $\mathrm{hGH}$ ) sequences as an intron-containing 3 '-noncoding segment/polyadenylation signal was employed previously as a necessary measure to generate appreciable levels of TGF- $\alpha$ in other tissues of transgenic mice (Sandgren et al. 1990). The K14/TGF- $\alpha /$ hGH fusion gene was then used to generate transgenic mice as described previously (Vassar et al. 1989). Fourteen founder mice tested positive for the transgene, as judged by Southern and polymerase chain reaction (PCR) analysis of their tail DNAs. Five of these mice were bred to generate transgenic lines for use in subsequent analyses.

Of founders harboring the K14-TGF- $\alpha$ transgene, eight showed morphological differences distinguishing them from normal mice (see Fig. 1: left, control littermate; right, transgenic mouse from an $F_{1}$ generation of founder mouse 10A). Similar to newborn mice injected subcutaneously with $2.7-4 \mu \mathrm{g} / \mathrm{gram}$ body weight/day of TGF- $\alpha$ (Smith et al. 1985; Tam et al. 1985), these eight transgenic neonates were underweight by an average of $30 \%$, and they showed precocious eyelid opening and tooth eruption at $\sim 6$ days of age (12 days for normal littermates). In addition, they exhibited marked skin abnormalities, which first appeared at 2 days of age and peaked between 1 and 2 weeks postbirth. Outer epidermal layers were flaky, skin was more wrinkled than normal, and hair growth was stunted. One of the mice was frail and subsequently died. Some showed only patches of affected skin, suggesting that these mice were mosaic for the transgene. Mosaicism was later confirmed by breeding, yielding mice whose skins were either $100 \%$ wild type or $100 \%$ abnormal (e.g., the two $\mathrm{F}_{1}$ littermates in Fig. 1). Many of the abnormal traits diminished within 5-6 weeks after birth, a feature also seen in $F_{1}$ offspring, and that was therefore inheritable. Most notably, epidermal scaliness disappeared over the body trunk and hair growth was partially restored. These observations were largely consistent with previous subcutaneous injection studies showing that adult mouse trunk skin does not respond to EGF (Cohen 1962; Cohen and Elliot 1963).

\section{Transgene expression and phenotype correlate in neonatal but not adult skin}

To assess why some transgenics were seemingly wild type and others exhibited skin abnormalities, we isolated skin RNAs from surviving 5-week-old founder mice and tested for the presence of rat TGF- $\alpha$ transgene mRNAs by Northern blot analysis (Fig. 2). Relative to K14 mRNA expression, six samples were judged negative for TGF- $\alpha-$ hGH mRNA expression (lanes 4, 8-12). These were from transgenic mice that were wild type in appearance. The other founder mice RNA samples contained an $\sim 2-\mathrm{kb}$ RNA that hybridized with a radiola- 
Figure 2. Northern blot analysis of K14-TGF- $\alpha$ transgenic mice RNAs. Back or tail skin RNAs were isolated from twelve 5-week-old founder mice and four 9-day-old $F_{1}$ transgenic mice, as described previously (Vassar et al. 1989). RNA samples [10 $\mu \mathrm{g}$ each (lanes 1-13); $20 \mu \mathrm{g}$ (lanes 14-17)] were resolved in duplicate by formaldehyde-agarose gel electrophoresis, transferred to nitrocellulose by blotting, and hybridized with radiolabeled probes corresponding to

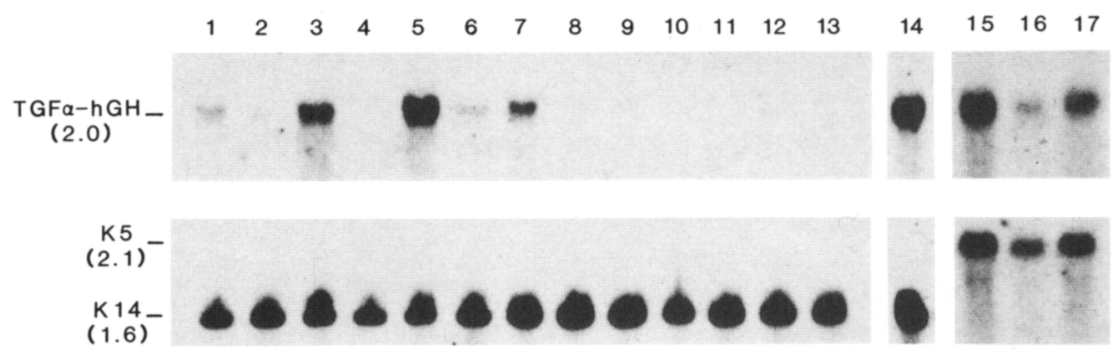
the 700-bp rat TGF- $\alpha$ cDNA (top; see Fig. 1) and either a 140-nucleotide mouse K14 cRNA (bottom; lanes 1-13), a 300-bp mouse K14 cDNA (bottom; lane 14) or a 1350-bp human K5 cDNA (bottom; lanes 15-17). After hybridization, blots were washed and exposed to $\mathrm{x}$-ray film. (Lanes 1-13) 5 days, top; 1 day, bottom; (lane 14) 2 days, top and bottom; (lanes 15-17) 1 day, top and bottom. Lanes 1-12 were from transgenic founder mice assigned the following numbers: (Lane 1) 10C; (lane 2) 10D; (lane 3) 10E; (lane 4) 10F; (lane 5) 10A; (lane 6) 10B; (lane 7) 10G; (lane 8) 10H; (lane 9) 10I; (lane 10) 10I; (lane 11) 10K; (lane 12) 10L. (Lane 13) Nontransgenic control mouse RNA; (lanes 14-17) RNAs from $F_{1}$ transgenics of founder mice 10A (lane 14), 10B (lane 15), 10M (lane 16), and 10D (lane 17). Founder mice 10D, 10B, and 10C were mosaic, as judged by the patchiness of their phenotype and their low expression of TGF- $\alpha$ RNA relative to offspring. In addition, a higher than expected percentage of wild-type offspring were observed from these founders. Numbers at left indicate RNA size in $\mathrm{kb}$.

beled probe complementary to rat TGF- $\alpha$ mRNA (lanes 1-3 and 5-7; see also lanes 14-17; $F_{1}$ generations from four different founder mice). The size of this RNA corresponded to that predicted for rat TGF- $\alpha$-hGH mRNA (Sandgren et al. 1990). When they were juveniles, all mice expressing TGF- $\alpha$-hGH mRNA exhibited skin abnormalities analogous to those shown in Figure 1. Furthermore, a correlation existed between the level of TGF- $\alpha$-hGH mRNA at 5 weeks and the severity of phenotype in newborns. Thus, although TGF- $\alpha-\mathrm{hGH}$ mRNA-expressing transgenic founders had few remaining phenotypic abnormalities by the time tail skins were taken for RNA analysis, their transgene mRNA levels were still readily detectable.

To examine the location and intracellular levels of TGF- $\alpha-h G H$ transgene mRNAs in skin, we hybridized serial sections of 5-day-old transgenic skins with radiolabeled cRNAs specific for transgene (rat TGF- $\alpha-h G H$ ) and mouse $\mathrm{K} 14$ mRNAs (Fig. 3A, bright field, TGF- $\alpha-h G H$; Fig. 3B, dark field, TGF- $\alpha-h G H$; C, K14). Paralleling the expression of endogenous K14 mRNAs, transgene mRNAs were localized in the innermost two to three layers of epidermis and in the outer root sheath (ORS) of hair follicles. By 5 weeks postbirth, TGF- $\alpha$-hGH mRNA expression remained high (Fig. 3D and $\mathrm{E}$, bright and dark field, respectively); but like K14 mRNA (Fig. 3F), it was localized to only a single (basal) layer of epidermis, in addition to ORS. In control mice, only very weak hybridization was seen with the TGF- $\alpha-h$ GH probe, and this was presumably due to cross-hybridization with endogenous mouse TGF- $\alpha$ mRNA (not shown). Moreover, control skins exhibited
Figure 3. In situ localization of transgene TGF- $\alpha$ and endogenous K14 mRNAs in skins from 5-day- and 5-week-old $F_{1}$ transgenic mice. Skin from the backs of $F_{1}$ transgenic mice was taken at 5 days $(A-C)$ and 5 weeks $(D-F)$ postbirth. Sections $\left(\sim 10 \mathrm{~mm}^{2}\right)$ were fixed in $4 \%$ paraformaldehyde and processed for in situ hybridization as described previously (Stoler et al. 1988). Sections were hybridized with $\left[{ }^{35}\right.$ S]UTPlabeled cRNA probes complementary to (1) the 2 -kb rat TGF- $\alpha-\mathrm{hGH}$ transgene mRNA $(A, B, D$, and $E)$ or (2) a 1.1-kb segment of human K14 mRNA that shares great homology with mouse K14 mRNA ( $C$ and $F$ ). After hybridizations, sections were washed, dipped in Kodak NTB2 liquid emulsion, and stored in the dark for 7 days at $4^{\circ} \mathrm{C}$ before developing. Localization of exposed silver grains was examined by bright-field and dark-field microscopy. Bar, $71 \mu \mathrm{m}$ for $A-F$.
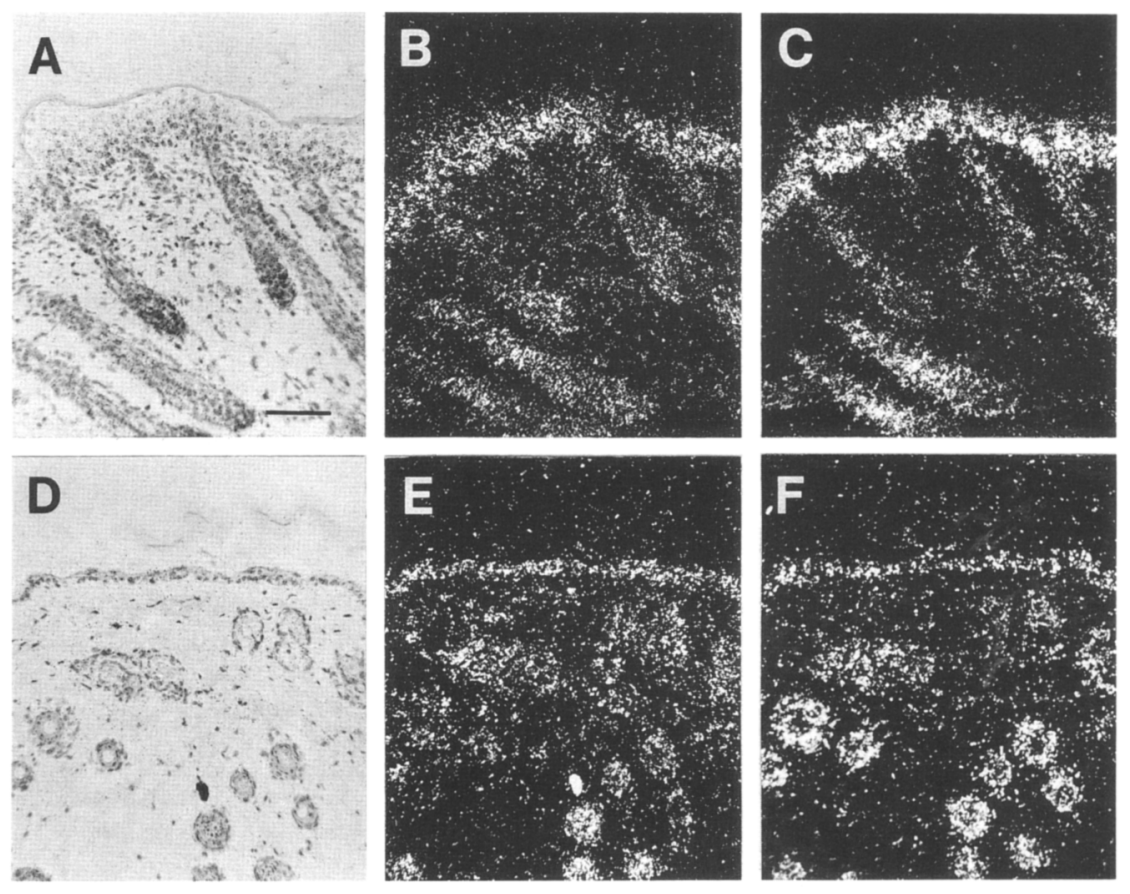
K14 mRNA hybridization patterns analogous to that shown in Figure 3F, irrespective of whether samples were taken at 5 days or 5 weeks postbirth. The seemingly altered $\mathrm{K} 14$ promoter activity in transgenic newborns was reminiscent of that observed for some hyperproliferative skin diseases in humans (Stoler et al. 1988) and in mice (Wilson et al. 1990). Despite this age-related difference in TGF- $\alpha$ transgene mRNA localization, the temporal phenotypic differences in the transgenics could not be attributed to a reduction in transgene expression.

To verify that the phenotype in newborn, TGF- $\alpha-h G H$ mRNA-expressing transgenics was a direct consequence of overproduction of transgene product, we used a radioimmune assay (Roberts et al. 1980; Sandgren et al. 1990) to quantitate mature (i.e., active) rat TGF- $\alpha$ in acid-ethanol extracts of skins of 9-day-old control mice and $F_{1}$ transgenics from two different founders (10A and 10B). Relative to rat TGF- $\alpha$ standards, the amount of TGF- $\alpha$ in control skin samples was $2 \mathrm{ng} / \mathrm{mg}$ of acid-ethanol extract, and in $F_{1}$ transgenic skins, it was 4 and $12 \mathrm{ng} / \mathrm{mg}$, respectively. These TGF- $\alpha$ levels were one to four times higher than those obtained in transgenic mouse studies where other promoters were used to drive overexpression of TGF- $\alpha$ in other tissues (Sandgren et al. 1990). Since the neonatal mortality rate of the $F_{1}$ offspring of our founder transgenic mice was considerable, TGF- $\alpha$ may be lethal when expressed at high levels in skin and other stratified squamous epithelia.

Histopathology of the epidermis of transgenic mice: more to psoriasis than TGF- $\alpha$

Histopathological examination revealed that TGF- $\alpha$ expressing epidermis was markedly thicker than the control /cf. Fig. 4A and B, transgenics, with Fig. 4C, control). Surprisingly, terminal differentiation was seemingly normal, with spinous, granular, and stratum corneum layers all increased proportionately to control epidermis. Both basal and spinous cells from TGF- $\alpha$ expressing mice, however, showed clear signs of hypertrophy; and in some cases, cells were almost twice the normal size (cf. Fig. 4A and B, transgenic, with Fig. 4C, control of same magnification). This was further verified by electron microscopy (see below). In addition, the dermis was markedly thinner than usual, with hair follicles often flattened and distorted at the dermal-subdermal border (cf. low magnifications in Fig. 4D, transgenic, vs. Fig. 4E, controll. The thinner dermis was a consequence of a thinner collagen matrix, rather than a decrease in the dermal fibroblast population. Because TGF- $\alpha$ can induce type 1 collagenase expression in epidermal keratinocytes (Y.-S. Choi and E. Fuchs, unpubl.), it seems likely that this may have contributed to a decrease in collagen matrix in K14-TGF- $\alpha$ mice.

Epidermal hypertrophy has been reported in acute eruptive guttate psoriasis vulgaris (Brody 1984) and may exist in other forms of psoriasis where elevated TGF- $\alpha$ levels have been reported (Gottlieb et al. 1988; Elder et al. 1989). In contrast, dermal atrophy has not been associated with psoriatic skin. Moreover, the histopathology of juvenile K14-TGF- $\alpha$ mouse epidermis differed markedly from that of human psoriatic skin (Fig. 4F), where the granular layer is often thinner and/or variable and nuclei persist in the stratum corneum layers (see inset in Fig. 4F; also see Fitzpatrick et al. 1987). Finally, no evidence of any major inflammatory response was observed in these young TGF- $\alpha$-expressing transgenic mice, and this is in marked contrast to psoriasis /arrowheads in Fig. $4 \mathrm{~F}$ inset denote leukocyte infiltration in psoriatic epidermis; arrowheads in Fig. 4F denote leukocyte infiltration in underlying dermis). Because leukocytic infiltration could be induced in 9-day-old mouse skin by chemoattractants such as Corynebacterium parvum (not shown; for method, see Rothstein and Schreiber 1988), it seems most likely that factors in addition to TGF- $\alpha$ are necessary to trigger the immune response associated with psoriasis.

In addition to the TGF- $\alpha$-induced histopathological changes in epidermis, some other stratified squamous epithelia known to express the K14 gene (Vassar et al. 1989| were also affected. Most notably, both ventral and dorsal epithelia of the tongue showed a proportional and prominent thickening (not shown). Less affected were the corneal and esophageal epithelium. Whether the lack of major phenotypic aberrations in some stratified squamous epithelia was a consequence of lower levels of transgene expression or, alternatively, a difference in TGF- $\alpha$ responsiveness, was not determined.

The effects of overexpression of the K14-TGF- $\alpha$ transgene were largely limited to stratified squamous epithelia and cells and structures within their immediate environment. This was directly illustrated by our mosaic founder mice, which exhibited alternating patches of scaly and normal epidermis. In addition, in contrast to studies where the metallothionine or mouse mammary tumor virus promoters were used to drive overexpression of TGF- $\alpha$ in transgenic mice (Jhappan et al. 1990; Matsui et al. 1990; Sandgren et al. 1990), no major changes in mammary epithelia, liver, pancreas, or intestine were detected. Collectively, these findings suggest that the effects of TGF- $\alpha$ in our K14-TGF- $\alpha$ transgenic mice were localized, and that little if any transgene TGF- $\alpha$ entered the bloodstream of these mice.

\section{Hyperproliferation, EGFR expression, and cell migration in transgenic keratinocytes in vivo and in vitro}

To test for differences in proliferative capacities of transgenic and control mouse epidermis, we incubated back skin biopsies from 5-day-old mice for $4 \mathrm{hr}$ in culture medium containing bromo-deoxyuridine (BrdU), as described by Sieweke et al. (1989). Inspection of many sections stained with a monoclonal anti-BrdU antibody revealed that approximately twice as many transgenic keratinocytes versus control keratinocytes were synthesizing DNA at the time of the pulse (for representative examples, see Fig. $4 \mathrm{G}$ and $\mathrm{H}$, respectively). The relative levels of BrdU-labeled basal cells paralleled the number of mitotic indexes in control and transgenic skin, and 


\section{Vassar and Fuchs}
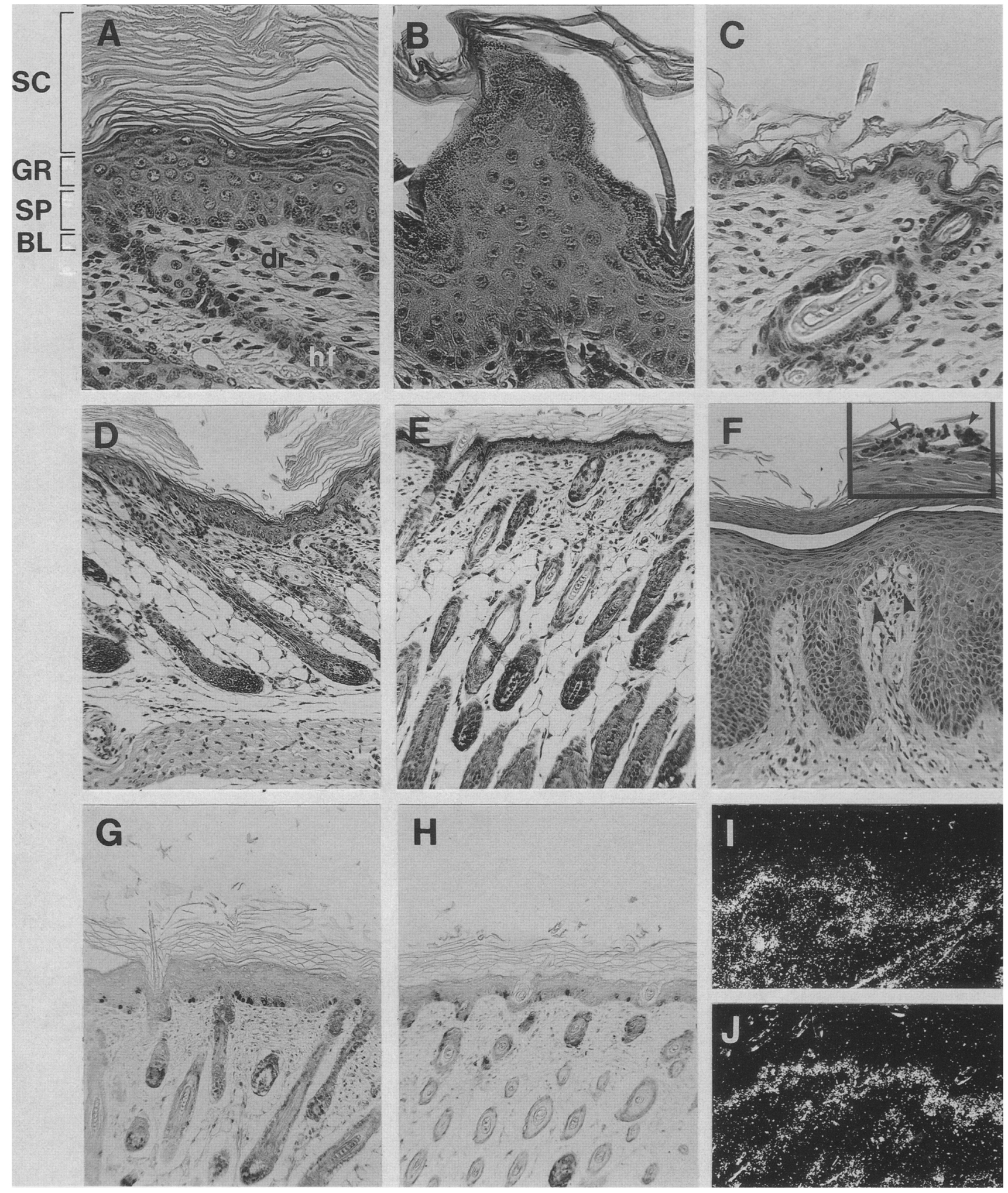

Figure 4. (See facing page for legend.)

indicated that the increase in number of epidermal cells per unit area of transgenic skin was due to an increase in proliferation within a single (basal) layer. By 5 weeks postbirth, differences in BrdU labeling of transgenic and control mouse back skin were no longer detected (not shown). 
We were intrigued by our finding that epidermal proliferation in TGF- $\alpha$-expressing transgenic mice was restricted to the basal layer, although TGF- $\alpha$ mRNA expression extended into the first few suprabasal layers. To investigate the possible basis for this, we examined the distribution of EGFRs in skin of transgenic and control mice. Indeed, EGFR expression was restricted to a single basal layer and ORS of both transgenic and control mice at both 9 days (Fig. 4I and J, respectively) and 5 weeks of age (not shown). The similarities in localization and levels of EGFRs in transgenic and control mice suggested that (1) EGFR expression was neither induced (suprabasal) nor appreciably altered (basal) by TGF- $\alpha$ overexpression, and (2) only cells expressing EGFR exhibited increased proliferation in response to TGF- $\alpha$ overexpression. Moreover, as EGFR levels are known to diminish in adult mice (Green et al. 1983), this suggests a likely basis for the disappearance of epidermal hyperproliferation with postnatal development.

TGF- $\alpha$ treatment of cultured human keratinocytes has been shown to result in epidermal proliferation and cell migration (Barrandon and Green 1987). When cultured in the absence of added growth factors, keratinocytes from 9-day-old transgenic mouse back skin reached confluence more than two times faster than those from a control mouse. Transgenic keratinocytes also exhibited long filiform projections, suggestive of an increase in cell migration capabilities (cf. Fig. 5A, transgenic, with Fig. 5B, control).

\section{Aberrancies in biochemical and morphological features of terminal differentiation}

Keratin expression is often used as a biochemical indicator of whether the program of epidermal differentiation is normal (see Weiss et al. 1984 and references therein). In normal epidermis, $\mathrm{K} 14$ and $\mathrm{K} 5$ are synthesized in the basal layer (Nelson and Sun 1983, Lersch and Fuchs 1988), and K1 and K10 are expressed in suprabasal layers (Fuchs and Green 1980). In a variety of hyperproliferative skin diseases, including psoriasis, K5 and K14 expression often extends into the suprabasal layers, and a new pair of keratins, $\mathrm{K} 6$ and $\mathrm{K} 16$, are induced in the differentiating cells (Weiss et al. 1984; Stoler et al. 1988).
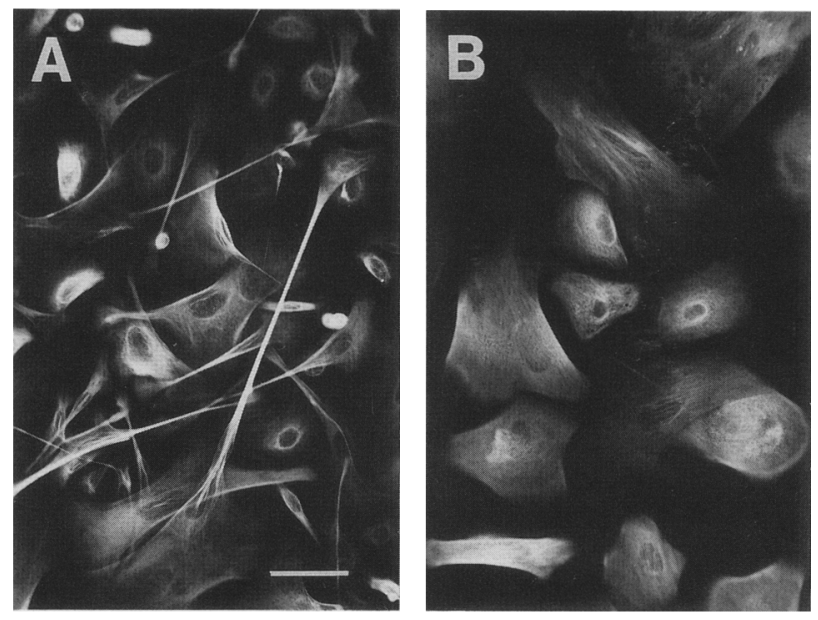

Figure 5. Cultured keratinocytes from 9-day-old transgenic and control mouse epidermis. Epidermal keratinocytes from 9day-old transgenic and control mouse back skins were cultured as described in Materials and methods. After growth, cells were fixed in methanol and stained with a $1: 100$ dilution of a guinea pig anti-hK5 antiserum in $20 \%$ normal goat serum. Cells were visualized after staining with a Texas red-conjugated goat antiguinea pig IgG (Cappel Laboratories). (A) Transgenic keratinocytes from mouse $F_{1}-10 G_{;}(B)$ control keratinocytes from a nontransgenic littermate. Bar in $A, 71 \mu \mathrm{m}$ for $A$ and $B$.

Although there is some evidence that translational control may contribute to several of these changes (Tyner and Fuchs 1986), the majority of changes appear to be at the level of mRNA expression (Knapp et al. 1987; Stoler et al. 1988; Wilson et al. 1990).

To determine whether some of the keratin changes typical of these diseases also occur in our TGF- $\alpha$ expressing transgenic mice, we stained sections of transgenic and control 9-day-old skin with antikeratin antisera (Fig. 6). Anti-K14 staining of transgenic skin was high in both basal and inner suprabasal layers (Fig. 6A), in contrast to control skin (Fig. 6B), where predominantly basal layer staining was seen. In addition, anti-K6 strongly stained suprabasal layers of transgenic epidermis (Fig. 6C), whereas it detected only hair follicles in control skin (Fig. 6D). Of the three antikeratin antisera

Figure 4. Histopathology, BrdU labeling, and ${ }^{125} \mathrm{I}$-labeled EGF binding to transgenic and control mouse skin. Sections (5 $\left.\mu \mathrm{m}\right)$ of skins fixed with Bouin's solution from 9-day-old $\mathrm{F}_{1}$ transgenics of founder mouse $10 \mathrm{~A}\left(\mathrm{~F}_{1}-10 \mathrm{~A}_{;} A\right.$ and $\left.D\right)$ and $10 \mathrm{~B}\left(\mathrm{~F}_{1}-10 \mathrm{~B} ; B\right)$, a 9 -day-old nontransgenic control $(C$ and $E)$, and an affected lesion from a patient with psoriasis $(F)$ were stained with hematoxylin and eosin. (BL) Basal layer; (SP) spinous layers; (GR) granular layers; (SC) stratum corneum. Note the difference in dermal thickness between transgenic $(D)$ and control $(E)$. Although the dermal-subdermal border of transgenic skin can be seen $(D)$, the border of control skin extended another $200 \mu \mathrm{m}$ below the edge of the figure frame $(E)$. Arrowheads in inset to $F$ denote leukocytes in stratum corneum layers; arrowheads in $F$ denote leukocytes in underlying dermis. $(G$ and $H) 1 \times 2$-mm samples of skin from a 5-day-old $\mathrm{F}_{1}-10 \mathrm{~A}$ transgenic $(G)$ and a control $(H)$ were placed for $4 \mathrm{hr}$ in medium containing BrdU. Samples were washed, fixed in $2 \%$ paraformaldehyde, and sectioned, followed by staining with an anti-BrdU antibody, immunogold labeling and silver enhancement (Sieweke et al. 1989). Representative skin sections are shown. Note that only the basal layer of the epidermis contains labeled cells. $(I$ and $J)$ Skin sections $\left(0.04 \mathrm{~cm}^{2}\right)$ from 9-day-old transgenic $\left(I ; F_{1}\right.$ offspring of founder 10A $)$ and control $(J)$ mice were incubated for 90 min in serum-free medium containing ${ }^{125}$ I-labeled EGF. Samples were washed extensively, sectioned, and subjected to autoradiography as outlined in Materials and methods. Sections were exposed to Kodak NTB2 liquid emulsion for 15 weeks before developing. Bar in $A, 29 \mu \mathrm{m}$ in $A-C$ and inset to $F$; $71 \mu \mathrm{m}$ in $D-I$. 


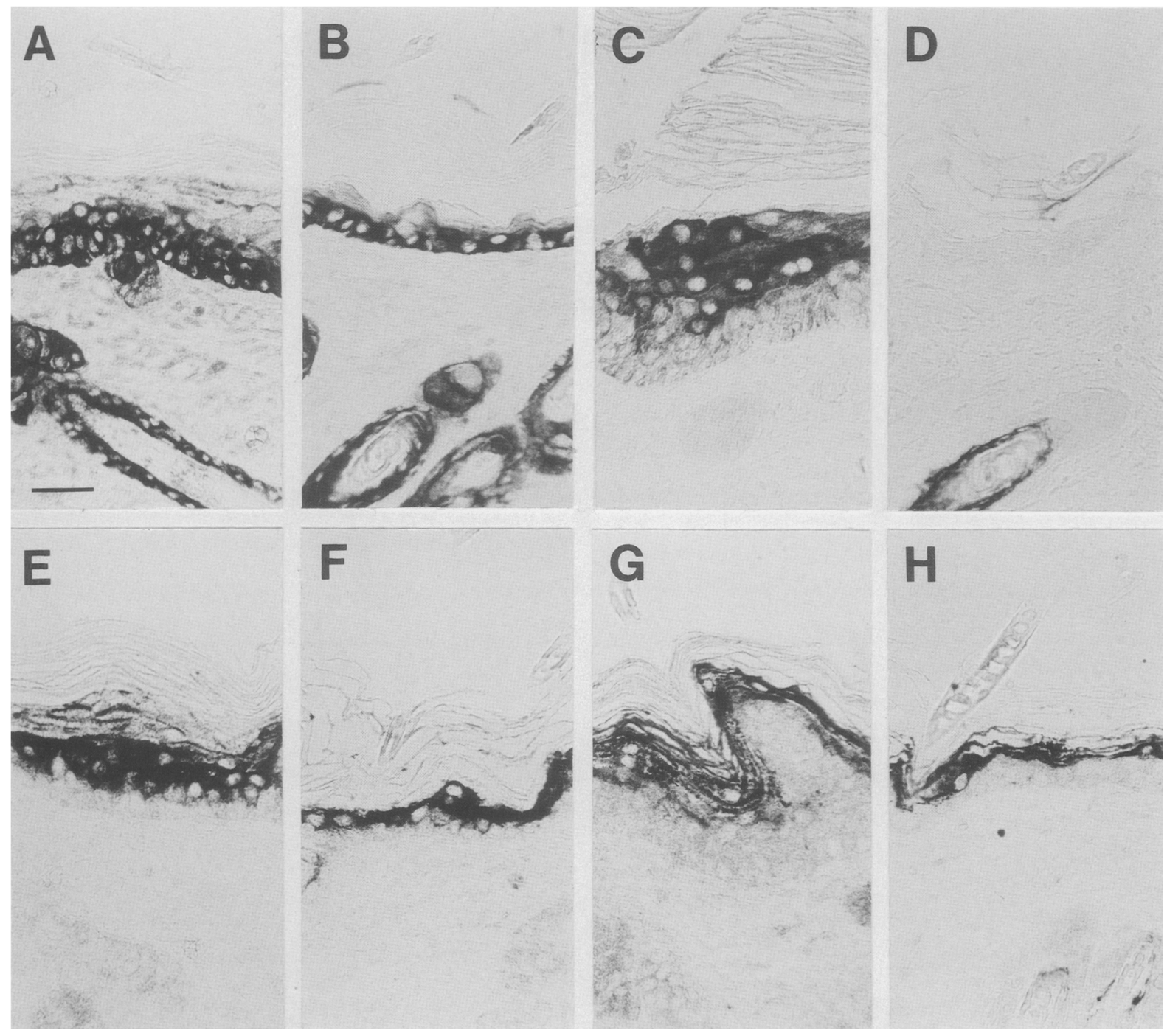

Figure 6. Expression of keratins and filaggrin in transgenic and control neonatal mice. Sections (5 $\mu \mathrm{m})$ of skins fixed with Bouin's solution from a 9-day-old $\mathrm{F}_{1}$ transgenic of founder mouse $10 \mathrm{~A}\left(\mathrm{~F}_{1}-10 \mathrm{~A} ; A, C, E\right.$, and $\left.G\right)$ and a nontransgenic control $(B, D, F$, and $H)$ were stained with anti-human K14 $(1: 200$ dilution; $A$ and $B$, respectively), anti-mouse $\mathrm{K} 6(1: 300$ dilution; $C$ and $D$, respectively), anti-mouse $\mathrm{K} 10$ ( $1: 300$ dilution; $E$ and $F$, respectively), and anti-mouse filaggrin $(1: 300$ dilution, $G$ and $H$, respectively). Details about the antisera and the conditions and procedures used for staining can be obtained from Choi and Fuchs (1990). Bar, $29 \mu \mathrm{m}$ for all frames.

used, only anti-K10 stained transgenic and control skin samples similarly (Fig. $6 \mathrm{E}$ and $\mathrm{F}$, respectively). In this case, differences in staining patterns between transgenic and control skins could be attributed to the increased numbers of spinous layers in transgenic mice. Collectively, the keratin patterns exhibited by our transgenic mice were similar to those seen for various hyperproliferative epidermal diseases (Weiss et al. 1984; Stoler et al. 1988).

To examine later stages of terminal differentiation, we stained sections with an antiserum against mouse filaggrin, an intermediate filament-associated protein expressed specifically in granular cells. The increase in granular layers in transgenic mice was readily apparent by antifilaggrin staining /cf. Fig. 6G, transgenic mouse skin, with Fig. $6 \mathrm{H}$, control skin). The pattern of antifilaggrin staining coupled with hypergranulosis in our transgenic mice was in contrast to psoriatic skin but was more similar to that of some other hyperproliferative diseases (Fitzpatrick et al. 1987).

Electron microscopy studies: epidermal hypertrophy suggests that TGF- $\alpha$ has a profound effect on cell metabolism

Electron microscopic examination of transgenic and control mouse epidermis allowed a more detailed comparison of morphological aberrancies arising from overexpression of TGF- $\alpha$ (Fig. 7). Epidermal hypertrophy induced by TGF- $\alpha$ overexpression was readily visible [cf. 

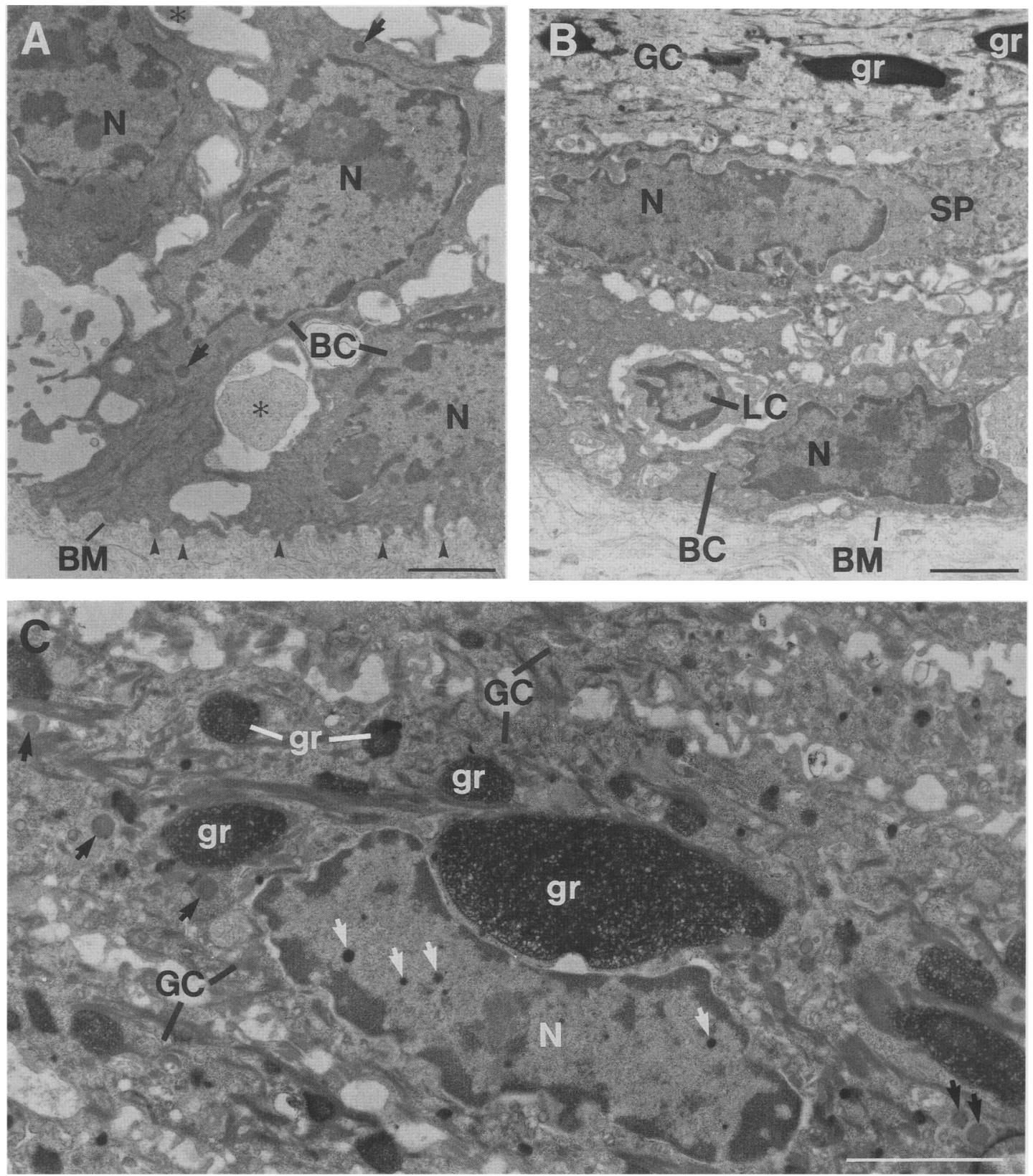

Figure 7. Electron microscopy of skin sections from transgenic and control neonatal mice. Skin samples $\left(2 \mathrm{~mm}^{2}\right)$ from 9 -day-old $\mathrm{F}_{1}$-10A transgenic $(A$ and $C)$ and control $(B)$ mice were fixed in $2 \%$ glutaraldehyde, postfixed in $1 \%$ osmium tetroxide, and embedded in LX-112 (Ladd Research Industries, Burlington, VT) as described previously (Coulombe et al. 1989). Sections were examined under a Philips CM10 electron microscope. Bars, $2 \mu \mathrm{m}$. (BC) Basal epidermal keratinocyte; (LC) leukocyte; (N) nucleus; (BM) basement membrane; $(\mathrm{GC})$ granular cell; $(\mathrm{SP})$ spinous cells; $(\mathrm{gr})$ keratohyalin granules. Asterisks $\left({ }^{\star}\right)$ indicate extracellular material especially abundant in transgenic epidermis. Arrowheads in $A$ denote undulations in the basal lamina of transgenic basal cells; white arrows in $C$ denote nuclear granules of unknown origin; black arrows in $A$ and $C$ denote cytoplasmic inclusions of unidentified material. Note: The nuclear granules and cytoplasmic inclusions were peculiar to transgenic cells and were not in the control cells.

Fig. 7A, transgenic basal cells (BC) with Fig. 7B, control basal cell $(B C)$ shown at same magnification]. Basal transgenic cells tended to be more columnar in shape and seemed more loosely interconnected than control basal cells. An abundance of extracellular material often filled these spaces (asterisks in Fig. 7A). In addition, spherical cytoplasmic inclusions (possibly lysosomes) of unidentified material were present in transgenic basal cells but not in control cells (see arrows in Fig. 7A). Transgenic basal cells also exhibited numerous short 
pseudopodial projections creating undulations in the basement membrane (arrowheads in Fig. 7A). Coupled with numerous filiform projections, these traits were similar to those of cultured transgenic keratinocytes and provided further evidence that TGF- $\alpha$ overexpression led to an increase in cell migration, in vivo as well as in vitro.

The repercussions of TGF- $\alpha$ overexpression were also seen in the nondividing, terminally differentiating epidermal cells. Thus, differences in cell size and extracellular material were even more striking for spinous (not shown) and granular cells (shown) than for basal cells [cf. Fig. 7B, control granular cell (GC), with that of transgenic granular cell in Fig. $7 \mathrm{C}_{\text {; }}$ note that magnification in Fig. $7 \mathrm{C}$ is 1.8 times that in Fig. $7 \mathrm{~A}$ and $\mathrm{B}$ ). Cytoplasmic inclusions were larger and more numerous in the upper layers (black arrows in Fig. 7C). In addition, a larger number of granular cells in transgenic epidermis retained their nuclei (see example in Fig. $7 C_{\text {; }}$ also see Fig. 4), and keratohyalin granules (gr) were generally larger and less dense than those in control granular layers /cf. Fig. 7C and $B$, respectively). In addition, small dense bodies of unknown origin were seen in nuclei of transgenic granular cells (see white arrows in Fig. 7C). Collectively, ultrastructural examinations of both mitotic and terminally differentiating transgenic epidermal cells revealed additional aberrancies that were not detected at the histological level.

Adult transgenic mice exhibit some peculiar abnormalities, including persistent ear and footpad epidermal thickening, genital epithelial aberrations, psoriatic-like lesions, and skin papillomas

By 5 weeks of age, the biochemical and morphological abnormalities described above had disappeared in most regions of transgenic epidermis. The only major histological difference persisting in the trunk region of adult mice was a thinner dermis and a decrease in hair follicle density, which was most apparent on the ventral surface. In contrast to the trunk region, several areas retained a highly thickened epidermis. This included the ear, which was thicker and somewhat more scaly and vascularized than normal (cf. transgenic adult in Fig. 8A with control adult in Fig. 8B). At the light microscopy level, it was readily apparent that the outer portion of the transgenic ear was greatly thickened [cf. Fig. 8C, outer (o) region of the ear, transgenic, with Fig. $8 \mathrm{D}$, control]. In contrast, the inner portion of the ear remained thin and largely unaffected [cf. inner (i) region of the ear].

Interestingly, several regions of the transgenic mouse ear epidermis showed leukocytic infiltration, both in the epidermis, and in the underlying dermis (Fig. 8E). In these localized areas, the granular layer was absent, giving a histological appearance similar to psoriatic skin. Control ear did not exhibit these psoriatic-like regions, nor were they observed in younger transgenic animals or in trunk regions of adult transgenic skin. Collectively, this phenotype seemed to be generated by a combination of TGF- $\alpha$ overexpression, TGF- $\alpha$ sensitivity, aging, and some other factor, perhaps mild mechanical irritation or bacterial infection.

Several other surface regions of adult transgenics were grossly affected by TGF- $\alpha$ overexpression. These included a thickened epidermis of the tail, footpads and rectal epithelium, longer nails, and in males, enlarged scrotum and foreskin (Fig. 8F, transgenic, and Fig. 8G, control; inset to F shows highly elongated nails). In mature females, the vaginal epithelium was also grossly enlarged and thickened (not shown). Curiously, the most affected areas of adult skin were those with a naturally thicker epidermis and with typically fewer hair follicles.

The original K14-TGF- $\alpha$ founder mice used in this study are now 10 months old, and none have shown evidence of squamous cell carcinoma tumorigenesis in any of the stratified squamous epithelia in which the K14 promoter is known to be active. Adult transgenics did, however, produce a limited number of benign skin papillomas. These developed almost exclusively in areas prone to self-induced mechanical abrasion and in areas previously subjected to scalpel incision (Fig. 9A and B, respectively). Histological investigation of the papillomas revealed a highly thickened and irregular epidermis, with vascularization and enlargement of the underlying dermis (Fig. 9C). In contrast, we have not observed papilloma formation at wounds or sites of irritation in control mice.

\section{Discussion}

TGF- $\alpha$, the balance between growth and differentiation, and psoriasis

Although cultured cells have provided useful models to examine the effects of TGF- $\alpha$ on keratinocyte growth and migration, transgenic mice have enabled an assessment of the effects of this growth factor on controlling the balance between growth and differentiation. In light of recent implications of TGF- $\alpha$ overexpression and psoriasis and in light of the gross phenotypic abnormalities in our newborn transgenic mice, we were surprised to discover that excess TGF- $\alpha$ had very little effect on the overall program of terminal differentiation. Rather, TGF- $\alpha$ proportionately increased the populations of basal, spinous, granular, and stratum corneum cells, and histologically, the only major difference in the keratinocytes seemed to be their enlarged size. Thus, although the biochemical program of terminal differentiation was characteristic of a number of hyperproliferative skin diseases, the changes in $\mathrm{K} 14 / \mathrm{K} 5$ and $\mathrm{K} 6 / \mathrm{K} 16$ expression did not seem to perturb the overall morphology of terminal differentiation. Indeed, cumulative studies over the past several years have indicated that the altered patterns of keratin expression often associated with hyperproliferative diseases can be attributed to environmental changes rather than hyperproliferation or abnormalities in the program of terminal differentiation per se (Mansbridge and Hanawalt 1988; Kopan and Fuchs 1989; Schermer et al. 1989; Stoler et al. 1989; Choi and Fuchs 1990). In addition to retinoids (Kopan and Fuchs 1989) and TGF- $\beta$ 

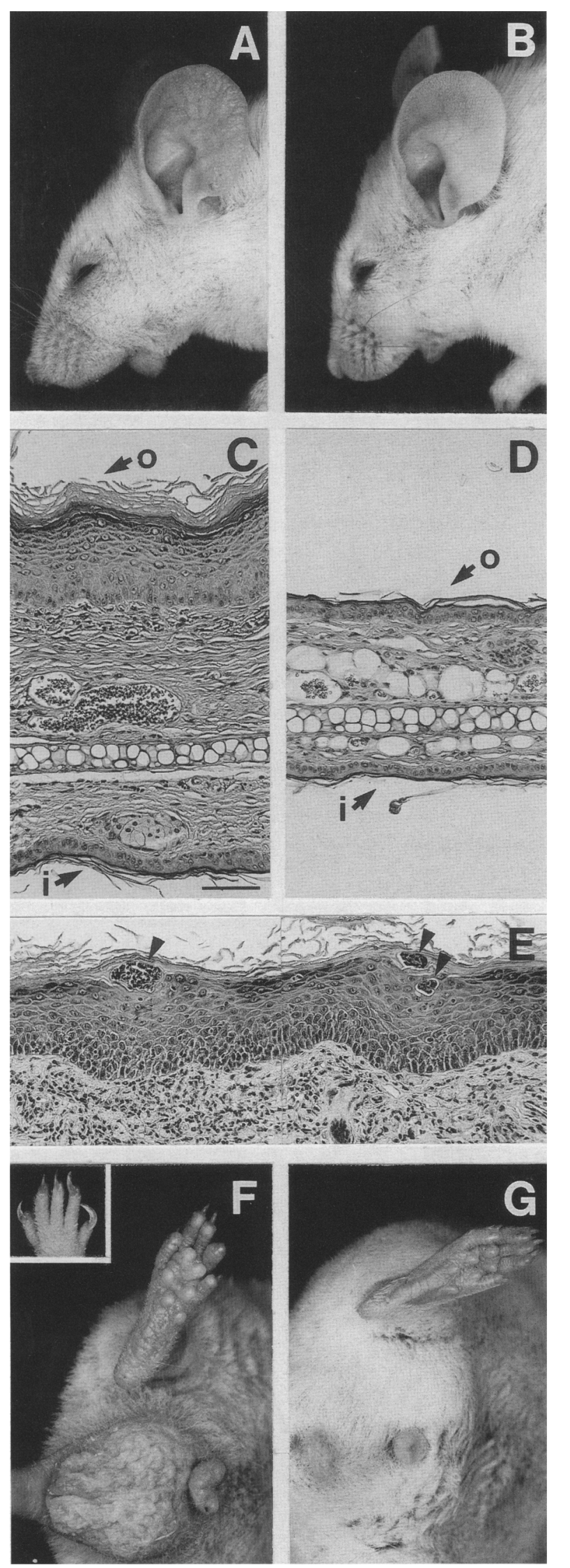

(Mansbridge and Hanawalt 1988; Choi and Fuchs 1989), TGF- $\alpha$ may now be included in this list of environmental factors.

Perhaps the most interesting aspect associated with the altered keratin pattern elicited by TGF- $\alpha$ was that these changes took place in the suprabasal epidermal layers. This was surprising as the growth-related effects mediated by elevated TGF- $\alpha$ levels were confined to the basal layer, where EGFRs were present on the cell surface. Although further studies will be necessary to elucidate the molecular basis underlying these effects, our findings suggest that either (1) the effects of TGF- $\alpha$ may be long lasting, and changes in basal cells may persist after their commitment to terminally differentiate, or (2) TGF- $\alpha$ overexpression may induce secondary changes in basal cells that in turn affect suprabasal cells, perhaps through production of a factor or cell-surface protein to which differentiating cells respond.

The finding that epidermal hyperplasia occurred in our transgenic mice provides evidence that the elevated levels of TGF- $\alpha$ in psoriatic skin (Gottlieb et al. 1988; Elder et al. 1989) may be relevant to the epidermal manifestations of the disease. Young TGF- $\alpha$ transgenic mice, however, not only exhibited a program of epidermal differentiation clearly distinct from psoriasis, but in addition, their skin showed no signs of gross leukocytic infiltration, which is a hallmark of psoriasis. In contrast, transgenic rats expressing one of the major histocompatability antigens, HLA B27, exhibited both epidermal alterations and leukocytic infiltrations highly similar to those of skin from patients with HLA-B27-associated reactive arthritis, a disease that includes skin abnormalities indistinguishable from some forms of psoriasis (Hammer et al. 1990). Interestingly, in this regard, a number of forms of psoriasis are often associated with specific HLA alleles in addition to elevated levels of TGF- $\alpha$ and other cytokines/receptors (for review, see Fitzpatrick et al. 1987).

A priori, it would seem that if overexpression of TGF- $\alpha$ plays a role in generating the psoriatic phenotype, then

Figure 8. Phenotypic abnormalities in surface epithelia from adult transgenic and control mice. $\mid A$ and $B \mid$ Head region of adult transgenic (line 10B) and control mice, respectively. Note the thickened appearance at the rim of the transgenic ear. $(C$ and D) Hematoxylin- and eosin-stained ear sections of transgenic and control mice, respectively, revealing gross thickening of the outer ear epidermis $(0)$ of the transgenic but virtually no difference in the inner ear epidermis (i). (E) Outer region of adult transgenic ear, indicating a segment with leukocytic infiltration in both the upper epidermal layers (arrowheads) and the underlying dermis (cf. control in $D$ ). Note that the epidermis in these affected areas is deficient in granular layers. Note also that this phenotype is similar to psoriatic human skin shown in Fig. 4F. ( $F$ and $G$ ) Genital area of adult transgenic and nontransgenic male, respectively, illustrating gross phenotypic enlargement of the scrotum and foreskin of the transgenic. Note also that the transgenic footpads are much larget than normal. The inset in $F$ shows unusually long nails, characteristic of adult transgenics. Bar in $C, 71 \mu \mathrm{m}$ for $C-E$. 


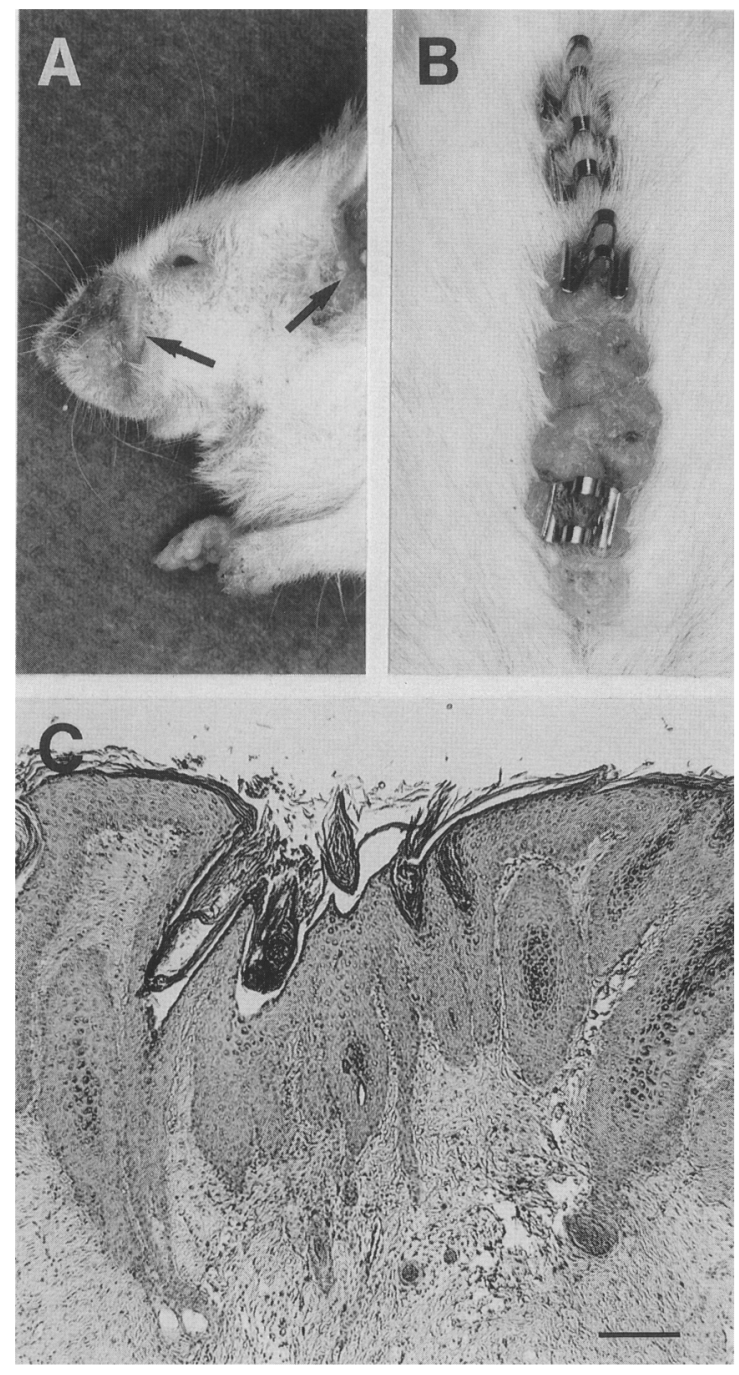

Figure 9. Papilloma formation at wound sites in adult transgenics. $(A)$ Head of founder transgenic $(10 \mathrm{~A})$, showing regions of papilloma formation around the nose and ear (denoted by arrows). $(B)$ Back of adult transgenic mouse $\left(F_{1}-10 A\right)$, which had been incised 3 months earlier to remove a sample of back skin for mRNA analysis. Note the presence of papillomas along the site of the incision. $(C)$ Section of papilloma (from $B$ ) fixed with Bouin's solution and stained with hematoxylin and eosin 15 $\mu \mathrm{m})$. Bar in $C, 180 \mu \mathrm{m}$.

the specific HLA expressed might be relevant to an earlier step in the pathway. Although this may be true, it is curious that localized regions of the outer ear skin of our adult TGF- $\alpha$-overexpressing transgenic mice exhibited characteristics of psoriatic plaques, including leukocyte infiltration and disappearance of granular layers. We have not yet elucidated the molecular basis for these lesions. However, since these localized aberrations (1) appeared only with age, (2) required sustained TGF- $\alpha$ sensitivity and TGF- $\alpha$ overexpression, and (3) were present in regions where mechanical irritation was frequent, it seems likely that bacterial infection coupled with TGF- $\alpha$ overexpression may have been responsible for triggering this response. Because incidences of psoriasis are known to increase with age, and as they involve localized regions of epidermal thickening and TGF- $\alpha$ elevation, TGF- $\alpha$ may still play an important role in the progression of the disease.

\section{TGF- $\alpha$ and EGFR regulation in epidermis}

A number of in vitro studies have suggested that TGF- $\alpha$ levels may influence expression of EGFRs (Clark et al. 1985; Earp et al. 1986; Kudlow et al. 1986). Although this may be true for some cells in culture, our in vivo studies argue against this mechanism operating in epidermis. Thus, we observed no major differences between EGFR levels in the basal epidermal layer of neonatal transgenic and control skins, although TGF- $\alpha$ levels varied considerably. Moreover, EGFR expression seemed unaffected by the synthesis of K14-TGF- $\alpha$ mRNAs in the first few suprabasal layers. Hence, despite overexpression of TGF- $\alpha$ in some spinous layers of transgenic epidermis, the down-regulation in EGFR levels still occurred at the basal-suprabasal transition, and hyperproliferation was restricted to the basal layer.

The progressive disappearance of epidermal hyperplasia in the trunk of adult K14-TGF- $\alpha$-expressing transgenics was reminiscent of the pioneering observation by Cohen and Elliott (1963) that EGF failed to enhance epidermal proliferation in adult mice, except for tail and footpads. Although the molecular basis for this has not been unequivocally elucidated, it is interesting that EGFRs on the surface of basal cells seem to be most abundant at birth and are down-regulated by $\sim 10$-fold at 4 weeks of age (Green et al. 1983). Moreover, in our studies, sensitivity to TGF- $\alpha$ was low in epidermal cells with no or few EGFRs in spite of sustained overexpression of the TGF- $\alpha$ transgene. Hence, it seems likely that developmental and differentiation-specific changes in EGFR levels have the greatest influence in controlling the TGF- $\alpha$ response in the epidermis.

\section{Epidermal hypertrophy and TGF- $\alpha$}

Cell hypertrophy has not usually been associated with TGF- $\alpha$ overexpression, and TGF- $\alpha$ is not a known regulator of generalized cellular metabolism. However, hypertrophy has recently been noted in liver cells that overexpress TGF- $\alpha$ (Jhappan et al. 1990), and in our transgenic mice, epidermal hypertrophy was a major consequence of TGF- $\alpha$ overexpression. We were especially intrigued by the finding that TGF- $\alpha$-mediated epidermal hypertrophy persisted in the terminally differentiating, but metabolically active, spinous layers. Because EGFRs are only prevalent on the surface of basal epidermal cells, it seems likely that the TGF- $\alpha$-mediated effects on cell size can continue after cells have ceased to divide and have lost most of their EGFRs.

We do not yet know how widespread the phenomenon of TGF- $\alpha$-induced cell hypertrophy might be. It is possible that TGF- $\alpha$-induced cell hypertrophy occurs in many 
tissues, and it is only by virtue of the well-defined architecture of stratified squamous epithelia that this effect was readily apparent. Alternatively, it may be limited to only a few tissues, such as stratified squamous epithelia (our studies) and liver hepatocytes (Jhappan et al. 1990). A knowledge of the cell type specificity of this phenomenon will be useful in elucidating the molecular basis underlying the response. Future studies will be necessary to determine how many steps are involved in the pathway and whether other cell types in the skin are involved in mediating these effects.

Has TGF- $\alpha$ evolved to be the determiner of epidermal thickness in mammals?

When we reviewed the effects of TGF- $\alpha$ on epidermal development and differentiation, we were struck by the strong correlation between sensitivity to TGF- $\alpha$ and regions that naturally require a thick protective epidermis to compensate for less hair. Thus, in newborn mice that have no hair, the epidermis is naturally thicker and nearly uniform in its sensitivity to TGF- $\alpha$ overexpression. In contrast, in adult mice, only a few regions of the skin have little or no hair and thus must maintain a more protective epidermis. These regions were the only ones to maintain their sensitivity to TGF- $\alpha$.

The extent to which TGF- $\alpha$ is specifically responsible for generating this phenotype is presently unknown. In at least three other models where abnormalities in epidermal growth and differentiation have been reported (Bailleul et al. 1990; Hammer et al. 1990; Wilson et al. 1990), however, transgene-related proportional thickening of epidermis did not seem to be restricted to those regions inherently thicker and sparse of hair. If, either directly or indirectly, TGF- $\alpha$ is the main determiner of epidermal thickness during development and differentiation, then the human trunk (which naturally has many fewer hair follicles and a thicker epidermis than furred mammals) might be expected to retain greater TGF- $\alpha$ sensitivity throughout development. Although further studies will be necessary to explore this notion, our TGF- $\alpha$ transgenic mice have uncovered a possible explanation for the differences in EGF and TGF- $\alpha$ sensitivity between newborn and adult mice, as well as an evolutionary basis for species-related differences in epidermal thickening and growth factor responsiveness.

\section{Epidermal papilloma formation, wounding, and TGF- $\alpha$}

TGF- $\alpha$ has been implicated with cultured epithelial transformation, but not with neoplastic progression in the skin (Finzi et al. 1988). The behavior of our K14-TGF- $\alpha$ transgenic mice was consistent with these studies. Thus, although elevated levels of TGF- $\alpha$ and/or EGFRs have been detected in squamous cell carcinomas (Ozanne et al. 1986; Gottlieb et al. 1988), TGF- $\alpha$ alone may not be sufficient for epidermal tumor formation.

An important finding of our work was the fact that our mice developed papillomas primarily at wounds or sites of irritation. In this regard, there were some similarities between our K14-TGF- $\alpha$ transgenic mice and recently derived K10-ras transgenic mice, where overexpression of the $\mathrm{H}$-ras oncogene in suprabasal epidermal layers also led to development of papillomas preferentially at sites exposed to mechanical irritation (Bailleul et al. 1990). Interestingly, despite targeting $\mathrm{H}$-ras gene expression to terminally differentiating keratinocytes, the tendency for papilloma formation seemed to be much greater in these mice than in our K14-TGF- $\alpha$ mice, where targeting was to the mitotically active basal cells. Direct comparisons of the in vivo effects of $H$-ras versus TGF- $\alpha$ were not possible, because preliminary attempts were unsuccessful in making transgenic mice expressing $\mathrm{H}^{-}$ ras in the basal layer (Bailleul et al. 1990). Although we observed TGF- $\alpha$ overexpression in some suprabasal layers, these cells were probably not responsive, as EGFRs seemed to be restricted to the basal layer. However, the collective observations are suggestive that TGF- $\alpha$ is less potent than $\mathrm{H}$-ras in contributing to papilloma formation.

The presence of benign tumors primarily at wound sites suggests strongly that factors produced in wounding must act in concert with TGF- $\alpha$ overexpression to cause papilloma formation. Although we have not yet investigated the nature of these factors, our results are strikingly similar to the observation that chickens infected with a pp $60^{\mathrm{v}-s r c}$-expressing retrovirus develop tumors at wound sites (Dolberg et al. 1980). Recently, a similar phenomenon has been noted for v-jun-expressing transgenic mice (Schuh et al. 1990). For Rous sarcoma virus-infected chickens, the wound stimulus leading to tumorigenesis has been identified as TGF- $\beta$ (Sieweke et al. 1990). Thus, it seems likely that TGF- $\beta$ s may also be the secondary factors leading to benign papilloma formation in our TGF- $\alpha$-expressing transgenic mice. Moreover, this leads to an interesting notion: Whereas TGF- $\alpha$ and TGF- $\beta$ combined might lead to benign tumors in epidermis, other oncogenic factors such as src and TGF- $\beta$ s might lead to malignant transformation. As additional transgenic mouse studies are conducted, the degree to which this hypothesis is accurate should become readily apparent.

\section{Materials and methods \\ Generation of transgenic mice}

The vector $\mathrm{pK14/TGF- \alpha /hGH}$ was constructed as outlined in the legend to Figure 1. Transgenic mice were generated as described (Vassar et al. 1989) and were identified by PCR and Southern blot analysis of ear or tail DNA. TGF- $\alpha$ transgene copy number varied from $<1$ (mosaic) to $\sim 20$ among the 14 founder mice chosen for this study.

\section{Radioimmune assay}

Skin was frozen in liquid nitrogen, ground to a powder, and extracted with acid-ethanol as described (Roberts et al. 1980). Extracts were reconstituted with glass-distilled water, and protein concentrations were determined by the method of Bradford. Tissue extracts were tested in duplicate at concentrations 
of 1 and $5 \mathrm{mg} / \mathrm{ml}$ in a TGF- $\alpha$ radioimmune assay. The assay measured the ability of extract to compete with ${ }^{125}$ I-labeled TGF- $\alpha$ for binding to an immobilized rabbit antiserum raised against the carboxyl terminus (i.e., mature form) of rat TGF- $\alpha$ (kit from BioTope, Redmond, WA).

\section{EGFR binding and distribution}

EGFR binding to skin sections was conducted essentially as described by Green et al. (1983). Briefly, skin samples $\left(0.04 \mathrm{~cm}^{2}\right)$ were incubated for $90 \mathrm{~min}$ at room temperature with gentle shaking in $0.5 \mathrm{ml}$ of Hank's balanced salt solution containing 1 $\mathrm{mg} / \mathrm{ml}$ of bovine serum albumin, $15 \mathrm{mM}$ HEPES (pH 7.3), and 10 $\mathrm{ng} / \mathrm{ml}$ of ${ }^{125} \mathrm{I}$-labeled EGF (sp. act. $100 \mu \mathrm{Ci} / \mu \mathrm{g}$ of EGF; Collaborative Research, Inc., Bedford, MA). After extensive washing, sections were fixed overnight in $3.5 \%$ paraformaldehyde $\left(4^{\circ} \mathrm{C}\right)$, embedded in paraffin and sectioned, and subjected to autoradiography using a Kodak NTB2 liquid emulsion. Sections were developed after 15 weeks of exposure at $4^{\circ} \mathrm{C}$.

\section{Transgenic mouse cultures}

Back skins of 9-day-old $F_{1}$ offspring of transgenic and control mice were cultured as described by Hennings et al. (1980). Cells were maintained in a low calcium $(0.04 \mathrm{~mm})$ version of a $3: 1$ mixture of Dulbecco's modified Eagle medium: Ham's F12 medium, supplemented with $15 \%$ fetal bovine serum (chelexed), $0.4 \mu \mathrm{g} / \mathrm{ml}$ of hydrocortisone, $1 \times 10^{-10} \mathrm{M}$ cholera toxin, $1 \times 10^{-11} \mathrm{M}$ insulin, $2 \times 10^{-10} \mathrm{M}$ triiodothyronine, and $5 \mu \mathrm{g} / \mathrm{ml}$ of human transferrin

\section{Acknowledgments}

We especially thank Pierre Coulombe for his supporting electron microscopy data and for his careful reading of the manuscript. We also thank Anton Callaway for analyses of transgenic mouse DNAs and Linda Degenstein for her continual willingness to provide technical expertise and assistance on various phases of the project. We thank Frank Dolbaere (Lawrence Livermore Laboratory, Livermore, CA) for anti-BrdU antibody, Richard Palmiter (University of Washington, Seattle, WA) for the MT/TGF- $\alpha /$ hGH construct, Dennis Roop (Baylor College of Medicine, Houston, TX) for anti-mouse K6 antiserum, Beverly Dale (University of Washington, Seattle, WA) for anti-mouse filaggrin antiserum, and Stuart Yuspa (National Institutes of Health, Bethesda, MD/ for anti-mouse K10 antiserum. We thank Michael Sieweke and Mina Bissell (Lawrence Berkeley Laboratory, Berkeley, CA) for their helpful comments regarding the BrdU-labeling assay, Hans Schreiber (Department of Pathology, University of Chicago, IL) for his helpful comments and advice regarding mouse skin immunology, and Maria Medenica (Department of Dermatology, University of Chicago, IL) for her valuable advice in evaluating the relationship between transgenic and psoriatic skin. We thank Clifford Stocks, Youngsook Choi, and Linda Degenstein for their help in constructing the K14/TGF- $\alpha / \mathrm{HGH}$ expression vector. Finally, we thank Philip Galiga for his artful presentation of the data. This work was supported by a National Institutes of Health grant. E.F. is an Investigator of the Howard Hughes Medical Institute; R.V. was a predoctoral trainee funded by a Molecular Biology Training Grant from the National Institutes of Health.

The publication costs of this article were defrayed in part by payment of page charges. This article must therefore be hereby marked "advertisement" in accordance with 18 USC section 1734 solely to indicate this fact.

\section{References}

Bailleul, B., M.A. Surani, S. White, S.C. Barton, K. Brown, M. Blessing, J. Jorcano, and A. Balmain. 1990. Skin hyperkeratosis and papilloma formation in transgenic mice expressing a ras oncogene from a suprabasal keratin promoter. Cell 62: 697-708.

Barrandon, Y. and H. Green. 1987. Cell migration is essential for sustained growth of keratinocyte colonies: The roles of transforming growth factor-alpha and epidermal growth factor. Cell 50: 1131-1137.

Bringman, T.S., P.B. Lindquist, and R. Derynck. 1987. Different transforming growth factor-alpha species are derived from a glycosylated and palmitoylated transmembrane precursor. Cell 48: 429-440.

Brody, I. 1984. Dermal and epidermal involvement in the evolution of acute eruptive guttate psoriasis vulgaris. I. Invest. Dermatol. 82: 465-470.

Choi, Y. and E. Fuchs. 1990. TGF-beta and retinoic acid: Regulators of growth and modifiers of differentiation in human epidermal cells. Cell Regul. 1: 791-809.

Clark, A.J.L., S. Ishi, N. Richert, G.T. Merlino, and I. Pastan. 1985. Epidermal growth factor regulates the expression of its own receptor. Proc. Natl. Acad. Sci. 82: 8374-8378.

Coffey, R.J., R. Derynck, J.N. Wilcox, T.S. Bringman, A.S. Goustin, H.L. Moses, and M.R. Pittelkow. 1987. Production and auto-induction of transforming growth factor-alpha in human keratinocytes. Nature 328: 817-820.

Cohen, S. 1962. Isolation of a mouse submaxillary gland protein accelerating incisor eruption and eyelid opening in the newborn animal. J. Biol. Chem. 237: 1555-1562.

Cohen, S. and G.A. Elliot. 1963. The stimulation of epidermal keratinization by a protein isolated from the submaxillary gland of the mouse. I. Invest. Dermatol. 40: 1-5.

Coulombe, P.A., R. Kopan, and E. Fuchs. 1989. Expression of keratin $\mathrm{Kl} 4$ in the epidermis and hair follicle: Insights into complex programs of differentiation. I. Cell Biol. 109: 22952312.

Derynck, R. 1988. Transforming growth factor-alpha. Cell 54: 593-595.

Derynck, R., D.V. Goeddel, A. Ullrich, J.U. Gutterman, R.D. Williams, T.S. Bringman, and W.H. Berger. 1987. Synthesis of messenger RNAs for transforming growth factors alpha and beta and the epidermal growth factor receptor by human tumors. Cancer Res. 47: 707-712.

Dolberg, D.S., R. Hollingworth, M. Hertle, and M.J. Bissell. 1980. Wounding and its role in RSV-mediated carcinogenesis. Science 230: 676-678.

Earp, H.S., K.S. Austin, J. Blaisdell, R.A. Rubin, K.T.G. Nelson, L.W. Lee, and J.W. Grisham. 1986. Epidermal growth factor (EGF) stimulates EGF receptor synthesis. I. Biol. Chem. 261: $4777-4780$.

Elder, J.T., G.J. Fisher, P.B. Lindquist, G.L. Bennett, M.R. Pittelkow, R.J. Coffey, L. Ellingsworth, R. Derynck, and J.J. Voorhees. 1989. Overexpression of transforming growth factor alpha in psoriatic epidermis. Science 243: 811-814.

Finzi, E., A. Kilkenny, J.E. Strickland, M. Balaschak, T. Bringman, R. Derynck, S. Aaronson, and S.H. Yuspa. 1988. TGFalpha stimulates growth of skin papillomas by autocrine and paracrine mechanisms but does not cause neoplastic progression. Mol. Carcinog. 1: 7-12.

Fitzpatrick, T.B., A.Z. Eisen, K. Wolff, 1.M. Freedberg, and K.F. 
Auster, eds. 1987. Dermatology in medicine, McGraw-Hill, New York.

Fuchs, E. and H. Green. 1980. Changes in keratin gene expression during terminal differentiation of the keratinocyte. Cell 19: 1033-1042.

Gottlieb, A.B., C.K. Chang, D.N. Posnett, B. Fanelli, and J.P. Tam. 1988. Detection of transforming growth factor alpha in normal, malignant, and hyperproliferative human keratinocytes. I. Exp. Med. 167: 670-675.

Green, M.R, D.A. Basketter, J.R Couchman, and D.A. Rees. 1983. Distribution and number of epidermal growth factor receptors in skin is related to epithelial cell growth. Dev. Biol. 100: 506-512.

Hammer, R.E., S.D. Maika, J.A. Richardson, J.-P. Tang, and J.D. Taurog. 1990. Spontaneous inflammatory disease in transgenic rats expressing HLA-B27 and human $\beta_{2} \mathrm{~m}$ : An animal model of HLA-B27-associated disorders. Cell 63: 1099-1112.

Hennings, H.D., M.C. Cheng, P. Steinert, K. Holbrook, and S.H. Yuspa. 1980. Calcium regulation of growth and differentiation of mouse epidermal cells in culture. Cell 19: 245-254.

Jhappan, C., C. Stahle, R.N. Harkins, N. Fausto, G.H. Smith, and G.T. Merlino. 1990. TGF alpha overexpression in transgenic mice induces liver neoplasia and abnormal development of the mammary gland and pancreas. Cell 61: 11371146.

Knapp, B., M. Rentrop, J. Schweizer, and H. Winter. 1987. Three cDNA sequences of mouse type I keratins: Cellular localization of the mRNAs in normal and hyperproliferative tissues. J. Biol. Chem. 262: 938-945.

Kopan, R. and E. Fuchs. 1989. The use of retinoic acid to probe the relation between hyperproliferation-associated keratins and cell proliferation in normal and malignant epidermal cells. J. Cell Biol. 109: 295-307.

Kudlow, J.E., M. Cheung, and J.D. Bjorge. 1986. Epidermal growth factor stimulates the synthesis of its own receptor in a human breast cancer cell line. J. Biol. Chem. 261: 4134 4138.

Lersch, R. and E. Fuchs. 1988. Sequence and expression of a type II keratin, K5, in human epidermal cells. Mol. Cell. Biol. 8: $486-493$.

Mansbridge, J.N. and P.C. Hanawalt. 1988. Role of transforming growth factor beta in the maturation of human epidermal keratinocytes. J. Invest. Dermatol. 90: 336-34l.

Massague, J. 1983a. Epidermal growth factor-like transforming growth factor. I. Isolation, chemical characterization and potentiation by other transforming factors from feline sarcoma virus-transformed rat cells. I. Biol. Chem. 258: 1360613613.

Massague, J. 1983b. Epidermal growth factor-like transforming growth factor. II. Interaction with epidermal growth factor receptors in human placenta membranes and A431 cells. J. Biol. Chem. 258: 13614-13620.

Matsui, Y., S.A. Halter, J.T. Holt, B.L.M. Hogan, and R.J. Coffey. 1990. Development of mammary hyperplasia and neoplasia in MMTV-TGF alpha transgenic mice. Cell 61: 1147-1155.

Nelson, W. and T.-T. Sun. 1983. The 50- and 58-kdalton keratin classes as molecular markers for stratified squamous epithelia: Cell culture studies. J. Cell Biol. 97: 244-251.

Ozanne, B., C.S. Richards, F. Hendler, D. Burns, and B. Gusterson. 1986. Over-expression of the EGF receptor is a hallmark of squamous cell carcinomas. J. Pathol. 149: 9-14.

Roberts, A.B., L.C. Lamb, D.L. Newton, M.B. Sporn, J.E. De Larco, and G.J. Todaro. 1980. Transforming growth factors: Isolation of polypeptides from virally and chemically transformed cells by acid/ethanol extraction. Proc. Natl. Acad. Sci. 77: 3494-3498.
Rothstein, J.L. and H. Schreiber. 1988. Synergy between tumor necrosis factor and bacterial products causes hemorrhagic necrosis and lethal shock in normal mice. Proc. Natl. Acad. Sci. 85: 607-611.

Sandgren, E.P., N.C. Luetteke, R.D. Palmiter, R.L. Brinster, and D.C. Lee. 1990. Overexpression of TGF alpha in transgenic mice: Induction of epithelial hyperplasia, pancreatic metaplasia, and carcinoma of the breast. Cell 61: 1121-1135.

Schermer, A., J.V. Jester, C. Hardy, D. Milano, and T.-T. Sun. 1989. Transient synthesis of $\mathrm{K} 6$ and $\mathrm{K} 16$ keratins in regenerating rabbit corneal epithelium: Keratin markers for an alternative pathway of keratinocyte differentiation. Differentiation 42: 103-110.

Schuh, A.C., S.J. Keating, F.S. Monteclaro, P.K. Vogt, and M.L. Breitman. 1990. Obligatory wounding requirement for tumorigenesis in v-iun transgenic mice. Nature 346: 756-760.

Sieweke, M.H., A.W. Stoker, and M.J. Bissell. 1989. Evaluation of the cocarcinogenic effect of wounding in Rous sarcoma virus tumorigenesis. Cancer Res. 49: 6419-6424.

Sieweke, M.H., N.L. Thompson, M.B. Sporn, and M.J. Bissell. 1990. Mediation of wound-related Rous sarcoma virus tumorigenesis by TGF-beta. Science 248: 1656-1660.

Smith, J.M., M.B. Sporn, A.B. Roberts, R. Derynck, M.E. Winkler, and H. Gregory. 1985. Human transforming growth factor-alpha causes precocious eyelid opening in newborn mice. Nature 315: 515-516.

Stoler, A., R. Kopan, M. Duvic, and E. Fuchs. 1988. The use of monospecific antibodies and cRNA probes reveals abnormal pathways of terminal differentiation in human epidermal diseases. I. Cell Biol. 107: 427-446.

Stoler, A., M. Duvic, and E. Fuchs. 1989. Unusual patterns of keratin expression in the overlying epidermis of patients with dermatofibromas: Biochemical alterations in the epidermis as a consequence of dermal tumors. I. Invest. Dermatol. 93: 728-738.

Tam, J.P. 1985. Physiological effects of transforming growth factor in the newborn mouse. Science 229: 673-675.

Tyner, A.L. and E. Fuchs. 1986. Evidence for posttranscriptional regulation of the keratins expressed during hyperproliferation and malignant transformation in human epidermis. $I$. Cell Biol. 103: 1945-1955.

Vassar, R., M. Rosenberg, S. Ross, A. Tyner, and E. Fuchs. 1989. Tissue-specific and differentiation-specific expression of a human K14 keratin gene in transgenic mice. Proc. Natl. Acad. Sci. 86: 1563-1567.

Weiss, R.A., R. Eichner, and T.-T. Sun. 1984. Monoclonal antibody analysis of keratin expression in epidermal diseases: A 48- and 56-kdalton keratin as molecular markers for hyperproliferative keratinocytes. /. Cell Biol. 98: 1397-1406.

Wilson, J.B., W. Weinberg, R. Johnson, S. Yuspa, and A.J. Levine. 1990. Expression of the BNLF-1 oncogene of Epstein Barr Virus in the skin of transgenic mice induces hyperplasia and aberrant expression of keratin 6. Cell 61: 1315-1327. 


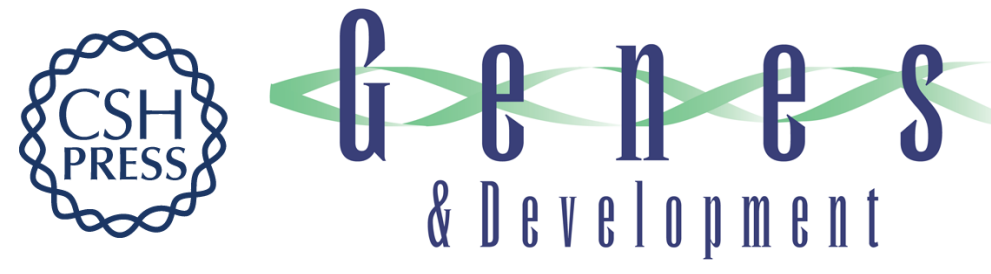

\section{Transgenic mice provide new insights into the role of TGF-alpha during epidermal development and differentiation.}

$R$ Vassar and E Fuchs

Genes Dev. 1991, 5:

Access the most recent version at doi:10.1101/gad.5.5.714

References This article cites 47 articles, 23 of which can be accessed free at:

http://genesdev.cshlp.org/content/5/5/714.full.html\#ref-list-1

License

Email Alerting

Service

Receive free email alerts when new articles cite this article - sign up in the box at the top right corner of the article or click here.

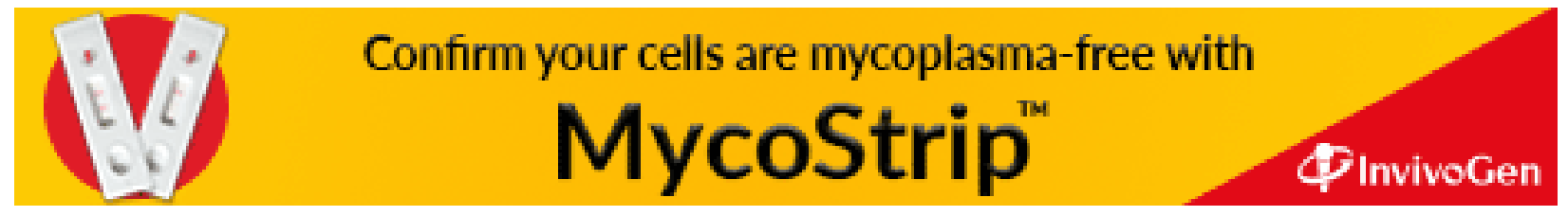

